\title{
Kinetics of Mango Fruits (Mangifera indica cv. 'Nam Dok Mai Si Thong') Quality Changes during Storage at Various Temperatures
}

\author{
Duangjai Noiwan ${ }^{1,2}$, Panuwat Suppakul ${ }^{3,4}$, Adisak Joomwong ${ }^{5}$, Jamnong Uthaibutra ${ }^{6}$ \& Pornchai Rachtanapun ${ }^{1,7,8}$ \\ ${ }^{1}$ Postharvest Technology Research Center, Faculty of Agriculture, Chiang Mai University, Chiang Mai, \\ Thailand \\ ${ }^{2}$ Graduate School, Chiang Mai University, Chiang Mai, Thailand \\ ${ }^{3}$ Department of Packaging and Materials Technology, Faculty of Agro-Industry, and Center for Advanced \\ Studies for Agriculture and Food (CASAF), Kasetsart University, Bangkok, Thailand \\ ${ }^{4}$ Department of Food Science and Biotechnology, and Center for Intelligent Agro-Food Packaging, College of \\ Life Science and Biotechnology, Dongguk University-Seoul, Goyang-si, Republic of Korea \\ ${ }^{5}$ Department of Biotechnology, Faculty of Science, Maejo University, Chiang Mai, Thailand \\ ${ }^{6}$ Department of Biology, Faculty of Science, Chiang Mai University, Chiang Mai, Thailand \\ ${ }^{7}$ Division of Packaging Technology, Faculty of Agro-Industry, Chiang Mai University, Chiang Mai, Thailand \\ ${ }^{8}$ Postharvest Technology Innovation Center, Commission on Higher Education, Bangkok, Thailand \\ Correspondence: Pornchai Rachtanapun, Division of Packaging Technology, Faculty of Agro-Industry, Chiang \\ Mai University, Chiang Mai 50100, Thailand. Tel: 666-3549-2556. E-mail: pornchai.r@cmu.ac.th
}

Received: February 23, $2017 \quad$ Accepted: April 15, $2017 \quad$ Online Published: May 15, 2017

doi:10.5539/jas.v9n6p199 URL: https://doi.org/10.5539/jas.v9n6p199

\begin{abstract}
Effect of various storage temperatures $\left(13,20,27\right.$ and $\left.34{ }^{\circ} \mathrm{C}\right)$ on biochemical, physical and physiological changes of mango fruits (Mangifera indica cv. 'Nam Dok Mai Si Thong') was investigated. Mangoes stored at low temperature revealed a decrease in their respiration rates. The lower respiration rates delayed ripening, ethylene production, weight loss, peel and flesh color changes, firmness, and total soluble solid content (SSC) as well as titratable acidity (TA). A second-order kinetic model, a Gaussian model, and a first-order kinetic model fitted well with response quality parameters on firmness, SSC and TA. The Arrhenius function was used to calculate the activation energies $(E a)$ of mango qualities including firmness, SSC and TA, which were 46.45, 43.05 and $54.22 \mathrm{~kJ} \mathrm{~mol}^{-1}$, respectively. These activation energies indicate a moderate temperature sensitivity of ripeness response and represent a good predictive tool for mango quality estimation along the food supply chain. The data reveal that stored mango fruit at $13{ }^{\circ} \mathrm{C}$ effectively prolongs the quality attributes and extends the shelf life of mango fruit.
\end{abstract}

Keywords: kinetics, mango, quality attribute, ripening, storage, temperatures

\section{Introduction}

Mango (Mangifera indica) cv. Nam Dok Mai Si Thong is one of the leading export products of Thailand. The quality and postharvest life of mango fruit depend on the harvesting time (Baloch \& Bibi, 2012). Therefore, the fruits are harvested at a suitable stage: normally, the mango fruit is harvested at 91-115 days after full bloom for the "Nam Dok Mai\#4" mango (Kienzle et al., 2012). The mango fruit continues to ripen rapidly after harvest (Zheng et al, 2007; Sothornvit \& Rodsamran, 2008). In the ripening fruit, physical, physiological, and biochemical changes occur, such as color change, change in the respiration rate, change in the rate of ethylene production, softening, increase in the sugar content, reduction in the change of organic acids, and production of volatiles compounds (Wills et al., 1998). The rate of ripening depends on the storage conditions, mainly the temperature. In general, the minimum temperature for storage of most tropical fruits is determined by their susceptibility to chilling injury. The optimum storage temperature of a mature-green mango is $12-14{ }^{\circ} \mathrm{C}$ (Mitra \& Baldwin, 1997; Sivakumar et al., 2011). Mango fruits cv. Tommy Atkins, Keitt, and Amelie were stored at $12{ }^{\circ} \mathrm{C}$ could be extended to 21 days, with no apparent signs of chilling injury (Medlicott et al., 1990). However, Mango fruits cv. Nam Dok Mai (Chongchatuporn et al., 2013), Kensington pride (Wang et al., 2008; Nair \& Singh, 2009) 
and Kensington (O'Hare, 1995) shows chilling injury symptoms when exposed to temperatures lower than about $13{ }^{\circ} \mathrm{C}$. The compositional change in the fruit is what is of concern for understanding the metabolic processes. Therefore, postharvest handling techniques are important for the development of a fruit industry.

Kinetic study of food products, especially horticultural produce is important due to the fact that the quality of food product is strongly dependent on their temperature exposure history, from production through distribution and storage to consumption (Bobelyn et al., 2006). The Arrhenius relation is a model widely used to describe quality loss and the effect of temperature on different physico-chemical properties (Olivera et al., 2012). The activation energy can be determined from the Arrhenius equation, and it is an empirical parameter characterizing the exponential temperature dependence of the rate constant (Schwaab \& Pinto, 2007). In particular, the activation energy indicates the temperature sensitivity of the quality deterioration. Activation energy values of a variety of food products are widely published. The Thai dessert "golden drop" during spoilage had $E_{a}=48.98 \mathrm{~kJ}$ $\mathrm{mol}^{-1}$ (Nopwinyuwong et al., 2010). Kimchi fermentation had $E_{a}=76.8 \mathrm{~kJ} \mathrm{~mol}^{-1}$ (Hong \& Park, 2000). For dry figs, this value varied from 30.8 to $48.47 \mathrm{~kJ} \mathrm{~mol}^{-1}$ (Babalis \& Belessiotis, 2004). However, very little information is available in the case of fresh fruits and vegetables (Pinheiro et al., 2013). Therefore, the main propose of this research are (1) to evaluate the effects of storage temperature on the change in quality of mango, (weight loss, firmness, soluble solid content, titratable acidity, and color change); and (2) to investigate the kinetics of mango and modelling its behavior as fraction of temperature.

\section{Material and Method}

\subsection{Materials}

Mango (Mangifera indica) cv. Nam Dok Mai Si Thong from the Northern of Thailand was taken for the study. Sodium hydroxide $(\mathrm{NaOH})\left(\mathrm{LAB}-\mathrm{SCAN}\right.$, Thailand) and Potassium hydrogen phthalate $\left(\mathrm{C}_{8} \mathrm{H}_{5} \mathrm{KO}_{4}\right)(\mathrm{Merck}$, Germany) were used to determine titratable acidity.

\subsection{Mango Sample Preparation and Collection}

Mango fruits were harvested at commercial maturity from Northern of Thailand and transported to the laboratory within an hour. Mangoes of uniformity, shape, size (380-400 grams), absence of defects due to cracks and diseases were selected. Mango fruits were stored at $13{ }^{\circ} \mathrm{C}, 20{ }^{\circ} \mathrm{C}, 27{ }^{\circ} \mathrm{C}$, and $34{ }^{\circ} \mathrm{C}$, respectively. In each treatment, nine fruits were used to determine each quality parameters every four days for $13{ }^{\circ} \mathrm{C}$, every two days for $20^{\circ} \mathrm{C}$ and $27^{\circ} \mathrm{C}$, as well as every day for $34^{\circ} \mathrm{C}$ until the fruit started showing signs of decay.

\subsection{Quality Assessment}

\subsubsection{Weight Loss}

Loss of weight was calculated progressively. The weight loss of the mangoes was determined by weighing at the beginning of the experiment and during storage. The same was expressed as the percentage loss of the initial weight [Equation (1)].

$$
\% \text { Weight loss }=\frac{\left(W_{0}-W_{t}\right)}{W_{t}} \times 100
$$

Where, $W_{0}$ is the weight of mango fruit on day zero; $W_{t}$ is the weight of mango fruit on day $t$; three replicates were carried out.

\subsubsection{Firmness}

Firmness of the mango flesh was measured after peeling the fruit using a texture analyzer (Model TA-XT2I/50, UK). The force required was taken from three different points with a $6 \mathrm{~mm}$ diameter cylindrical probe into the flesh of the fruit. The depth and the compression speed were $5 \mathrm{~mm}$ and $1 \mathrm{~mm} / \mathrm{sec}$, respectively. The firmness measurements were recorded and expressed in units of Newton $(\mathrm{N})$.

\subsubsection{Soluble Solid Contents (SSC) and Titratable Acidity (TA)}

Juice samples were obtained by squeezing the mango fruit. The SSC was determined with a digital refractometer (ATAGO Model PAL1, Japan) and expressed as a percentage. Before taking readings, the refrectometer was standardized with distilled water and adjusted to a reading of $0 \%$. The TA was determined by titration with 0.01 $\mathrm{N} \mathrm{NaOH}$ to a $\mathrm{pH}$ of 8.2 (AOAC, 2000), and calculated as the citric acid equivalent.

\subsubsection{Color Measurement}

Fruit color as peel and flesh color were measured with Color Reader (Minolta Model CR-300, Japan). The color was recorded using the CIE- $\mathrm{L}^{*} \mathrm{a}^{*} \mathrm{~b}^{*}$ uniform color space, where " $\mathrm{L} *$ " indicates lightness, "a*" indicates 
chromaticity on the green (-) to red (+) axis, and " $\mathrm{b}^{*}$ " indicates chromaticity on the blue (-) to yellow (+) axis. Each measurement was taken at the top, center, and bottom of the fruit.

\subsubsection{Respiration Rate}

Respiration rates were assessed by the flow system method (Fonseca et al., 2002). The fruits were placed in individual $4 \mathrm{~L}$ air-tight jars. Gas was passed over the fruit, with the air flow was maintained by a capillary tube. The carbon dioxide inside these containers was measured using gas chromatography (Agilent Technologies Model 6820 , USA) by using a model equipped with a thermal conductivity detector (TCD). The injection volume was $5 \mathrm{ml}$ headspace gas. The temperatures of the column, injector, and detector were 60,100 , and $150{ }^{\circ} \mathrm{C}$, respectively. The respiration rates were expressed as $\mu \mathrm{g} \mathrm{CO}_{2} \mathrm{~kg}^{-1} \mathrm{hr}^{-1}$.

\subsection{Kinetics Parameter Study}

The degradation kinetics of mango qualities were described by fitting a zero order Equation (2), a first-order Equation (3), a second-order kinetic model Equation (4) or following Taoukis (2001) Equation (5) to the experimental data.

$$
\begin{gathered}
F(X)=\left[X_{0}\right]-\left[X_{t}\right] \\
F(X)=\ln \left[X_{0}-X_{t}\right] \\
F(X)=\frac{1}{X_{0}}-\frac{1}{X_{t}} \\
F(X)=\sqrt{\ln \left(\frac{1}{1-X}\right)}
\end{gathered}
$$

Where, $\left[X_{t}\right]$ is the values of firmness, SSC and TA for a fixed storage time and temperature; $\left[X_{0}\right]$ is the initial values of firmness, SSC and TA.

The firmness, SSC, and TA were measured which used the corresponding value $X$ as the dynamic parameter, and the relation can be expressed in terms of the response function as follows:

$$
F(X)=k t
$$

Where, $X$ is the measured quality factor (firmness, SSC, and TA); $k$ is the rate constant of the reaction that is correlated with temperature; $t$ is the storage time.

By plotting a curve between the response function of total color difference $F(X)$ and time, a straight line could be obtained, and the $k$ of different storage temperatures could be calculated from the slope. Taking the natural logarithm on both sides of the Arrhenius function:

$$
\ln k=\ln A+E_{a} / R T
$$

by plotting a curve between $\ln k$ and $1 / T$, a straight line was obtained. The activation energy could be calculated from the slope, and $A$ from the intercept directly.

\subsection{Experimental Design and Statistical Analysis}

The experimental setup was arranged in a completely randomized design (CRD) with four storage temperatures and three replication used. Data were subjected to two-way analysis of variance (ANOVA) using SPSS software 16.0 version. Least significant difference values (LSD: $p \leq 0.05$ ) were calculated for mean separation. In order to afford predictive models of firmness, SSC and TA as a function of storage times and temperatures, a multiple regression were applied.

\section{Results and Discussion}

\subsection{Quality Assessment}

\subsubsection{Weight Loss}

The effects of storage temperature on weight loss of the mango fruit was shown in Figure 1. When the storage period was prolonged, the weight loss linearly increased during all the storage temperatures. This weight loss significantly was minimized by lowering temperature. The rate of weight loss at higher temperature was greater than that of weight loss at lower temperature. With decreasing storage temperatures from 34 to $13{ }^{\circ} \mathrm{C}$, the rate of weight loss obviously decreased from $2.25 \%$ to $0.46 \%$ per day. Loss of weight in fresh fruits and vegetables is mainly due to the loss of water caused by transpiration and respiration processes (Zhu et al., 2008). High storage temperature can be attributed to an increase in the rate of transpiration and anacceleration in fruit ripening, leading to higher respiration activity (Chiumarelli et al., 2011; Hoa \& Ducamp, 2008). These findings are also in 
agreement with the study of Sothornvit and Rodsamran (2008) which revealed that cold storage considerably retards the weight loss of mangoes in comparison with ambient storage.

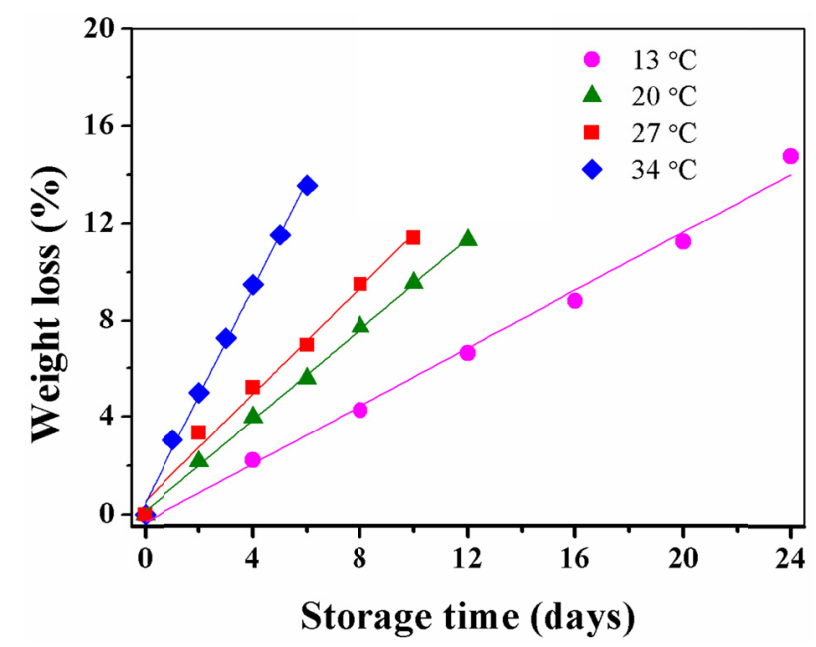

Figure 1. Effect of storage temperature on weight loss of 'Nam Dok Mai Si Thong' mango

\subsubsection{Firmness}

A decrease in the firmness of flesh was in association with a change in the mango fruit ripening (data not shown). The mature mango fruit had a firmness of about $48 \mathrm{~N}$ at the initial day of storage (day 0 ). Mango fruit with fresh characteristics "firmness" (between 33 to $44 \mathrm{~N}$ ) storage during 4, 2, 2 days at 13,20,27 ${ }^{\circ} \mathrm{C}$ are shown in Figure 2. Mango fruits kept at $34{ }^{\circ} \mathrm{C}$ yielded the highest rate of softening compared to the fruits kept at 27,20 and $13{ }^{\circ} \mathrm{C}$. Low storage temperatures delayed fruit softening and affected the activities of the fruit softening enzymes in the flesh, thus slowing down its textural deterioration. Mango fruit reached a stable stage after fully ripening until the end of storage (Figure 2). This finding is similar to the results obtained by Ketsa et al. (1998). Loss of firmness is because of the degradation of the cell wall constituents and polysaccharides by the action of polygalacturonase and pectin esterase on the solubilization of pectin substrates (Ali et al., 2004; Iagher et al., 2002; Yashoda et al., 2007). The higher storage temperatures induce the more activity of solftening enzymes. It has also been reported that the fruit had a little change in firmness during low temperature $\left(10^{\circ} \mathrm{C}\right)$ but softened once the temperature was rised to 20 or $25^{\circ} \mathrm{C}$ (Diaz-Perez et al., 2000). Ripened Langra and Samar Bahisht Chaunsa mango fruits showed significantly higher firmness when stored at $20{ }^{\circ} \mathrm{C}$ in comparison with higher storage temperatures of 30 and $40{ }^{\circ} \mathrm{C}$ (Baloch \& Bibi, 2012).

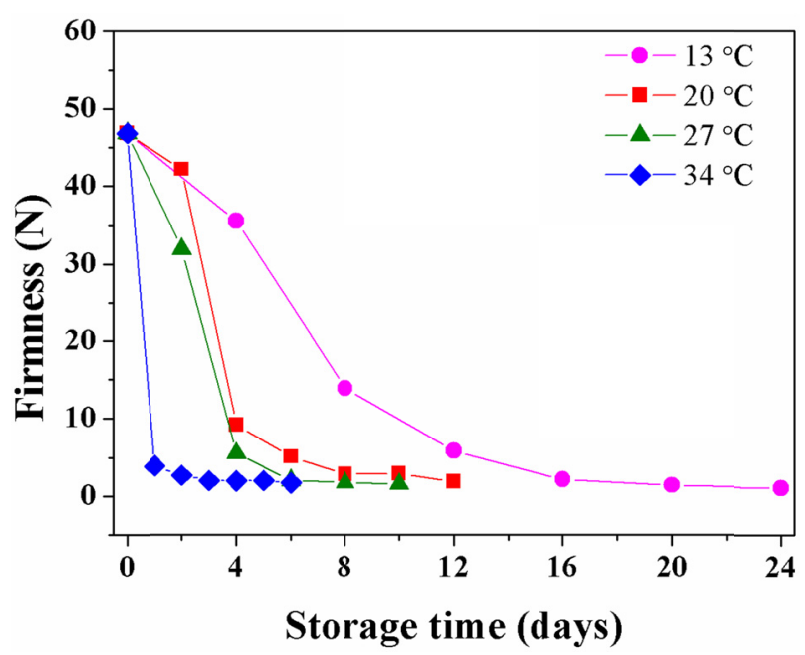

Figure 2. Effect of storage temperature on firmness of 'Nam Dok Mai Si Thong' mango 


\subsubsection{Soluble Solid Content (SSC) and Titratable Acidity (TA)}

Figure 3a shows the effect of storage temperature on the soluble solid content (SSC) of the "Nam Dok Mai Si Thong" mango. The SSC of the mango fruit was found to be increased with fruit ripening process. The SSC of the mature mango fruit was about $11 \%$ (day 0 ), and it continuously increased to approximately $16-17 \%$ when the fruit ripped. The levels of SSC after mango fruit fully ripened were observed to stable or slightly decline until the end of storage. As a climacteric fruit, an initial SSC of mango increased and followed by a subsequent decrease in SSC until reaching a full stage of senescence (Tefera et al., 2007). A conversion of carbohydrate into simple sugars through a complex mechanism was a cause of an increase in SSC of the fruit during storage (Baloch \& Bibi, 2012; Kays, 1999). Higher storage temperature yielded a rapid increase in the SSC of the mango fruit. At $34{ }^{\circ} \mathrm{C}$, the fruit revealed the shortest time for ripening ( 3 days) and higher SCC than those of mango fruits stored at 27,20 and $13{ }^{\circ} \mathrm{C}$. A delay in a change of the SSC indicates a prolongation of the postharvest life (Sothornvit \& Rodsamran, 2008).

Figure $3 \mathrm{~b}$ shows changes in the TA of the mango fruit at different storage temperatures. The TA was found to decrease during the ripening of the fruit in all conditions. On the initial day, the TA of the mature fruit was about $2.8-3.0 \%$, and decreased to about $0.2-0.9 \%$ in ripe mango fruits. The concentration of organic acids declines during ripening because of a conversion of citric acid into sugars and their further utilization in metabolic process of the fruit (Wills et al., 1998; Srinivasa et al., 2002; Gupta \& Jain, 2014; Famiani et al., 2015), and these are especially consumed during the respiration process (Hernández et al., 2006; Gomez \& Lajolo, 2008; Ibarra-Garza et al., 2015). High temperature has an impact on the TA of mango during storage. The TA of the fruit at $34{ }^{\circ} \mathrm{C}$ was observed to decrease faster than at 27,20 and $13{ }^{\circ} \mathrm{C}$. During the storage, the mango kept at $34{ }^{\circ} \mathrm{C}$ was found to ripen in the fourth day. The TA was found to be the lowest compared to the unripen fruit in other conditions. In general, the ripening rate of mangoes as indicated by a fall in the acidity was found to be much slower upon the cold storage than upon the ambient condition. The relatively higher storage temperature led to a higher rate of reduction in the TA during the ripening and storage of mangoes. The increase of SSC (Figure 3a) and decrease of TA (Figure 3b) could be related to the ripening stage of mango fruit during storage at various temperatures as reported by O'Hare (1995). 

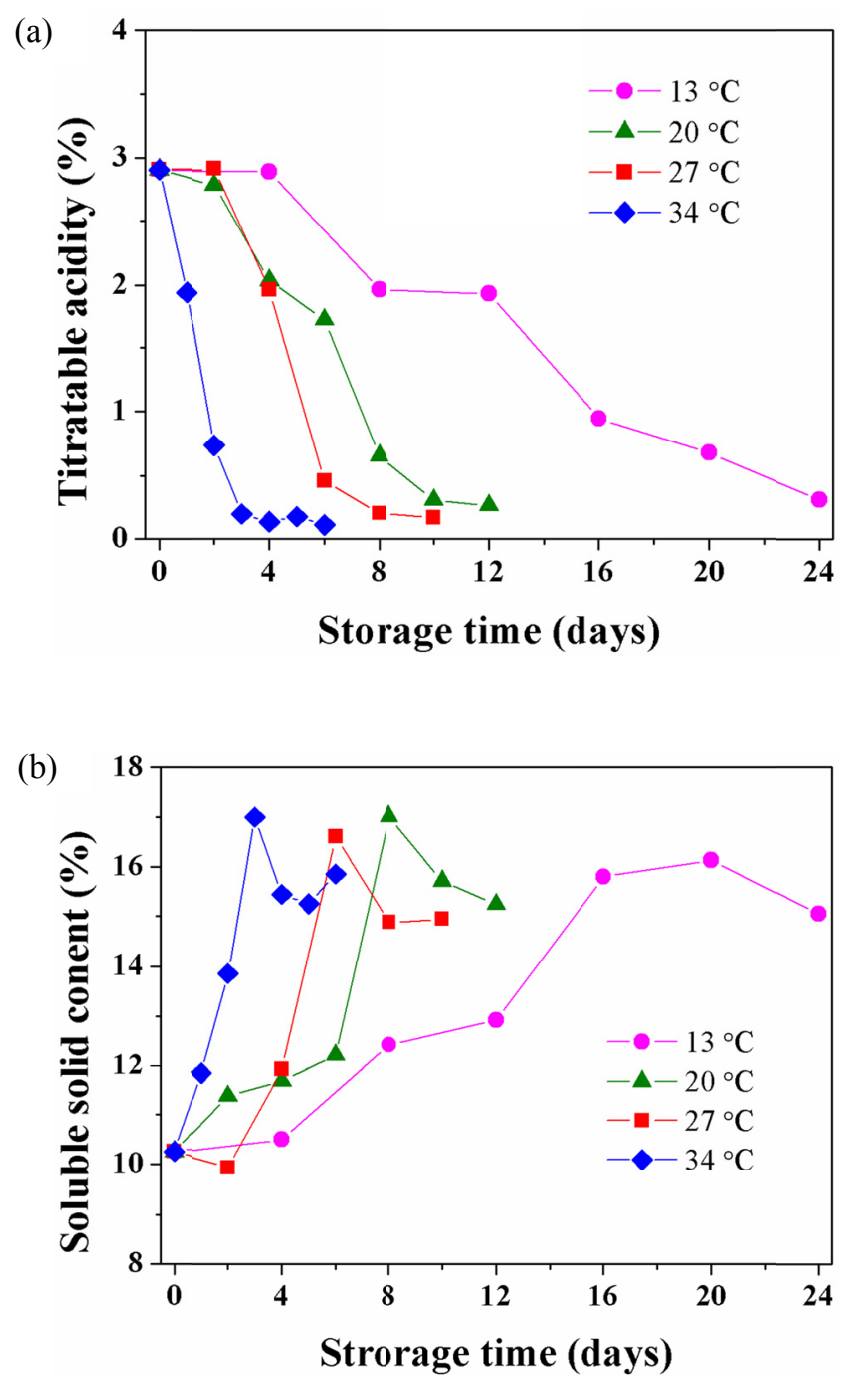

Figure 3. Effect of storage temperature on (a) soluble solid content and (b) titratable acidity of Nam Dok Mai Si Thong' mango

\subsubsection{Color Measurements}

It observed that the peel color of the mangoes changed from light yellow in the mature fruit to a dark yellow or a golden yellow color in the ripe mango. Figure 4 shows the $L^{*}$ value of the mango fruit stored at different temperatures. All the storage conditions showed continuous decrease in the $\mathrm{L}^{*}$ value (lightness) and increase in the $b^{*}$ value during the ripening of the mango fruit. The low temperature condition reduced the chromaticity $L^{*}$, $a^{*}$, and $b^{*}$ values during the storage. At the fully ripe stage, the chromaticity $\mathrm{L}^{*}$, and $\mathrm{a}^{*}$ values were lower and the $b^{*}$ value was higher in the fruit keep at $34^{\circ} \mathrm{C}$ irrespective of the storage period (Figures $4 a-4 c$ ).

The flesh color $\left(\mathrm{L}^{*}, \mathrm{a}^{*}\right.$, and $\left.\mathrm{b}^{*}\right)$ of the mango fruit at different storage temperatures are presented, respectively, as revealed in Figure 5a-5c. In general, The flesh color of the mango fruit changed from white color in the mature fruit to a dark yellow color in ripped mango; thus. It is evident that the $\mathrm{L}^{*}$ value decreased, while the $\mathrm{a}^{*}$ value increased when the fruit ripening. At the fully ripe stage (day $3,6,8$, and 16 for $34,27,20$, and $13{ }^{\circ} \mathrm{C}$, respectively), the chromaticity $\mathrm{L}^{*}$ and $\mathrm{b}^{*}$ values of the mango fruit were not significant $(p>0.05)$ between the different storage conditions. 
(a)

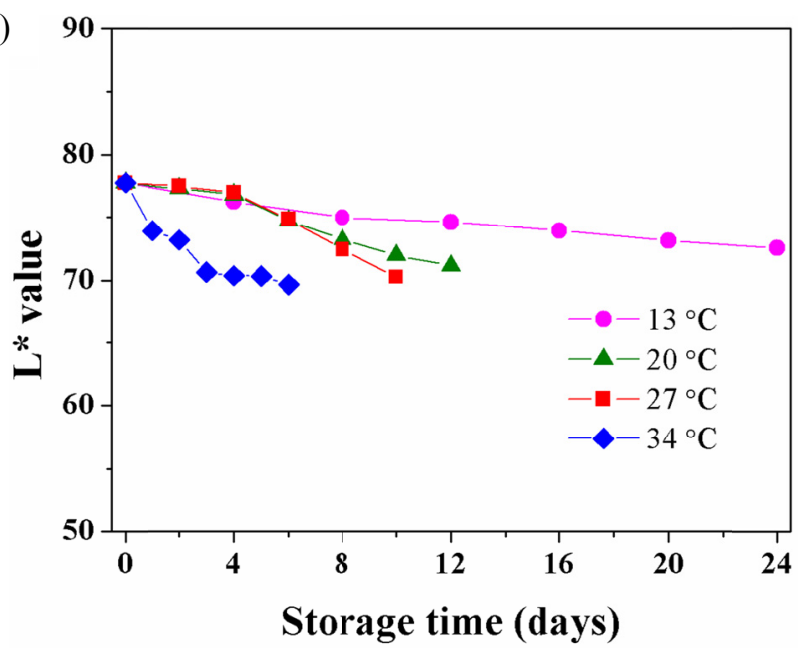

(b)

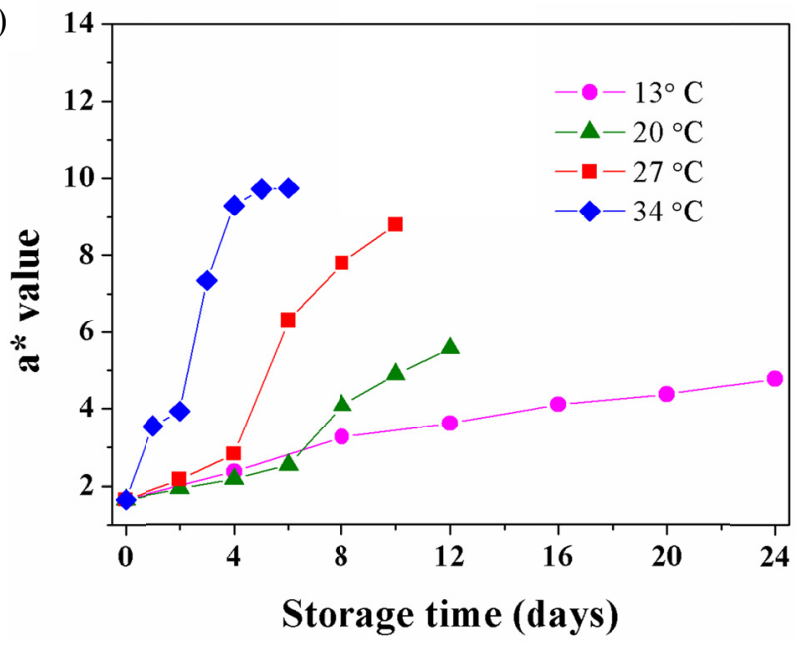

(c)

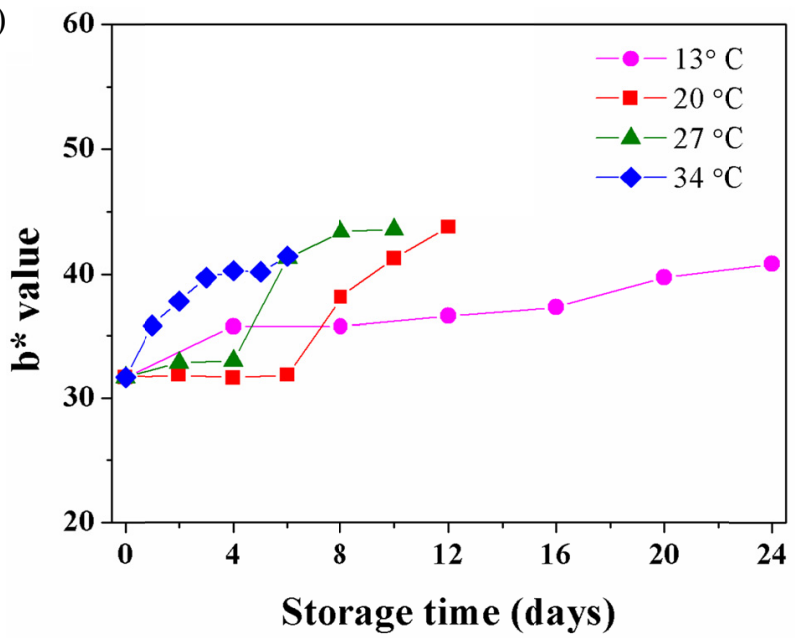

Figure 4. Effect of storage temperature on (a) L*, (b) a * and (c) b* value (peel) of 'Nam Dok Mai Si Thong' mango 
(a)

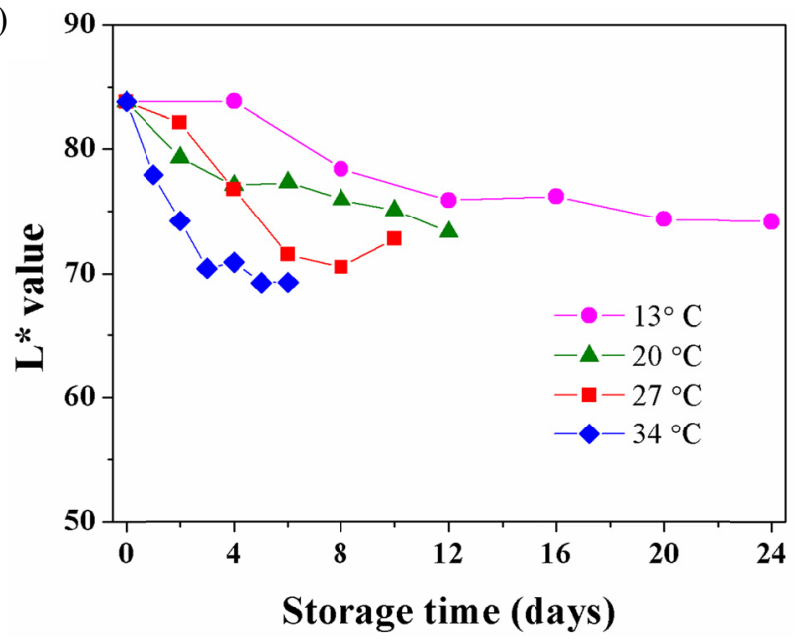

(b)

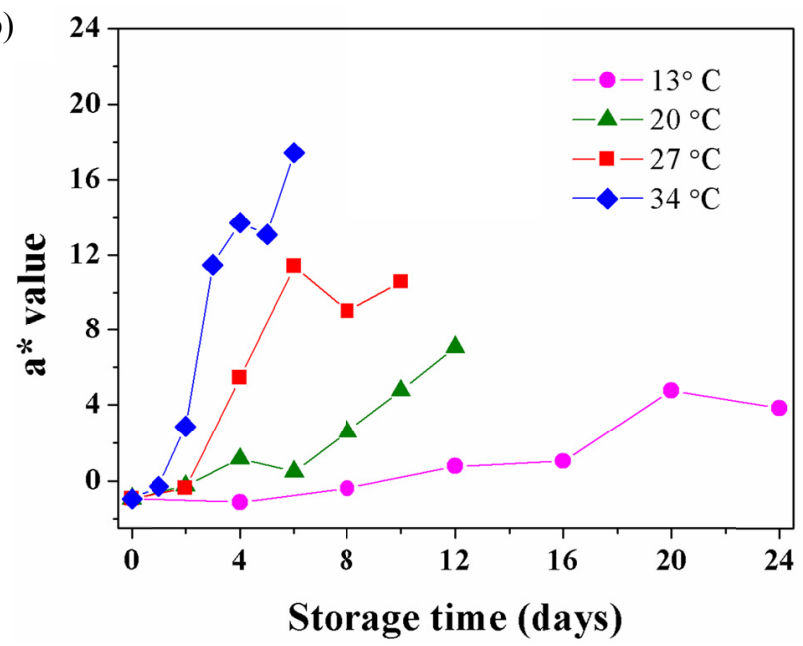

(c)

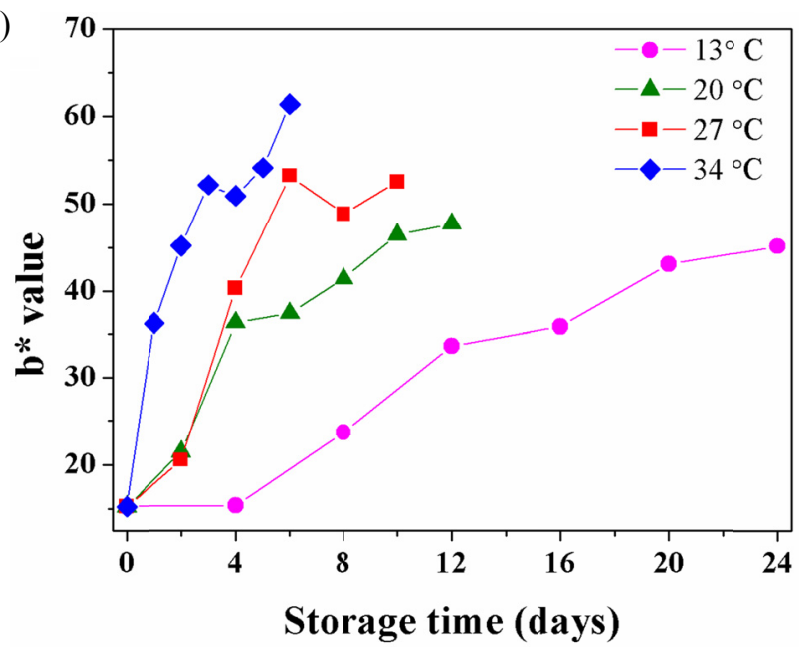

Figure 5. Effect of storage temperature on (a) $\mathrm{L}^{*},(\mathrm{~b}) \mathrm{a} *$ and (c) $\mathrm{b}^{*}$ value (flesh) of 'Nam Dok Mai Si Thong' mango 


\subsubsection{Respiration Rate}

The respiration rates of the mango fruits at different storage temperatures are depicted in Figure. 6. An initial respiration rate of the mango fruits at $13{ }^{\circ} \mathrm{C}$ was of the lowest value $\left(84.52 \mu \mathrm{g} \mathrm{CO}_{2} \mathrm{~kg}^{-1} \mathrm{hr}^{-1}\right)$ compared to their respiration rates of $101.02,130.86$, and $208.8 \mu \mathrm{g} \mathrm{CO}_{2} \mathrm{~kg}^{-1} \mathrm{hr}^{-1}$ stored at 20,27 , and $34{ }^{\circ} \mathrm{C}$, respectively. There was a statistically significant difference $(p<0.05)$ among respiration rates of mango fruits kept at different storage conditions. Mango showed a characteristic pattern of climacteric, which is a stage of fruit ripening related to increased ethylene production and a rise in cellular respiration. Climacteric is the final physiological process that marks the end of fruit maturation and the onset of fruit senescence. The climacteric pattern of Nam Dok Mai Si Thong mango fruit ripening is similar to the observations reported by other studies (Medlicott et al., 1986; Diaz-Perez et al., 2000; Zaharah \& Singh, 2011; Zheng et al., 2007). Low storage temperatures can suppress the respiration rate, and this would provide a decrease in the metabolic activities, delaying fruit deterioration and, thus, increasing the postharvest life of the fruit. The fruit kept at higher temperatures had a climacteric peak earlier than the fruit kept at lower temperatures. Mango reached a climacteric peak three days after harvest when it was kept at $34^{\circ} \mathrm{C}$, while its climacteric peaks of the kept fruit at 27,20 , and $13{ }^{\circ} \mathrm{C}$ were 6,8 , and 16 days, respectively. The respiration rates at the climacteric peak of the mangoes fruit kept at $34,27,20$, and $13{ }^{\circ} \mathrm{C}$ were $582.6,420.4,243.1$, and $189.5 \mu \mathrm{g} \mathrm{CO}_{2} \mathrm{~kg}^{-1} \mathrm{hr}^{-1}$, respectively. This behavior indicates that low storage temperatures alter the respiration rate in the mango fruit, resulting in delayed ripening and climacteric peak occurrence (Diaz-Perez et al., 2000). Similar behavior was noticed by Zaharah and Singh (2011), as well, in their investigation with the "Kensington Pride" mango. In this study, the quality attributed including firmness, $\mathrm{SSC}, \mathrm{TA}$, color changes and respiration rate revealed a relative delay in ripening process in similar manner.

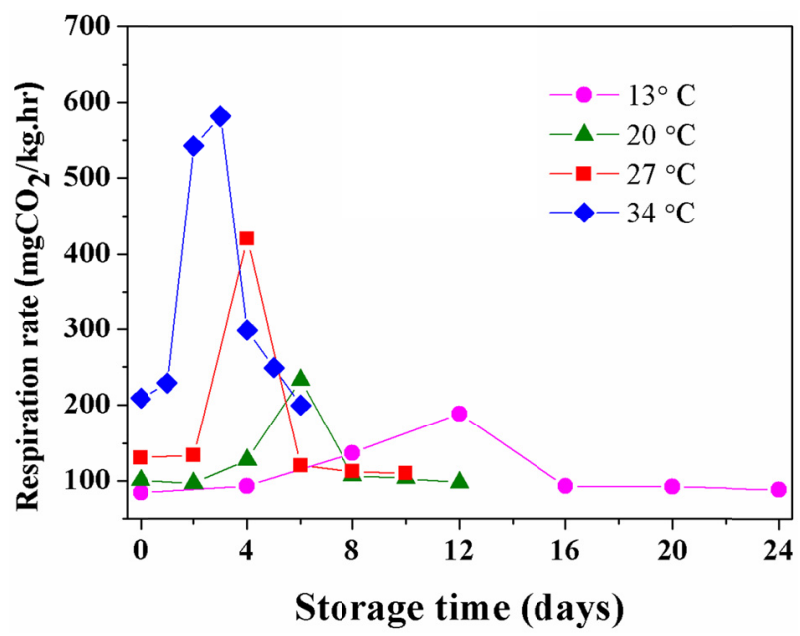

Figure 6. Effect of storage temperature respiration rate of 'Nam Dok Mai Si Thong' mango

\subsection{Kinetics Parameter Study}

Firmness, SSC, and TA value are ripening index of mango fruit. During the ripening process, firmness and TA of fruits decrease, whereas SSC increases. Therefore, the values of firmness, SSC, and TA were selected to study the kinetics of mangoes ripening. The $E_{a}$ value was calculated from the Arrhenius equation and the $E_{a}$ indicates the temperature sensitivity of the fruit ripening. Firmness, SSC, and TA, which changed at different temperatures as a parameter of the mango fruit ripening, showed sigmoidal behavior (Figures 2 and 3). The evolution of the TA value with storage time was fitted with a first-order kinetic model [Equation (3)], while firmness and SSC values were fitted with a second-order kinetic model [Equation (4)] and a Gaussian kinetic model [Equation (5)] (Taoukis, 2000), respectively.

Plotting the function $F(X)$ with storage time should result in four straight lines of different slopes at the different temperatures, as shown in Figures 7a-7c for firmness, SSC, and TA, respectively. The estimated kinetic parameters as the rate constants $(k)$ and the coefficients of determination $\left(R^{2}\right)$ are given in Table 1 . The $R^{2}$ of all the function parameters was satisfactorily moderate to high (in the range of 0.7021-0.9547, as shown in Table 1), which proves the adequacy of the model. Due to the temperature dependence, the Arrhenius equation [Equation (7)] was used to explain that the temperature dependence described well with the firmness, SSC, and TA values. 
Based on the changes in the firmness, SSC, and TA of the mango fruit during ripening, the values of $E_{a}$ as 46.45 , 43.05, and $54.22 \mathrm{~kJ} \mathrm{~mol}^{-1}$, respectively, could be estimated (Table 1). These activation energies indicate a moderate temperature sensitivity of the deteriorate response. In addition, these activation energies were obtained differing by less than $25 \mathrm{~kJ} \mathrm{~mol}^{-1}$. Thus, firmness, SSC, and TA could be accurately modeled of the degradation mechanisms involved and used to predict the influence of storage conditions on critical quality parameters. Moreover, the activation energy was useful information about the effects of different storage temperature conditions on quality of mango that directly affect consumer preference and helpful tools to define optimal storage conditions for maximum quality of mango (cv. 'Nam Dok Mai Si Thong'). Literature concerning kinetics model of fresh produces was found for tomato cv. "Zinac", the Arrhenius fractional conversion model fitted with the data on color ( $\mathrm{a}^{*}$ and $\mathrm{h}$ values), firmness, and weight loss parameters which have values of $E_{a}=84.4,87.6$, 64.8 , and $86.4 \mathrm{~kJ} \mathrm{~mol}^{-1}$, respectively (Pinheiro et al., 2013).

(a)

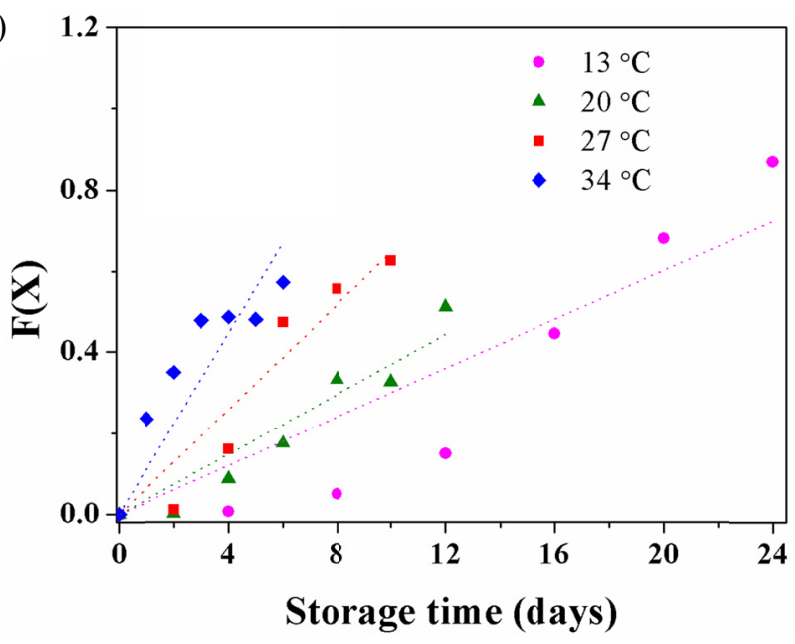

(b)

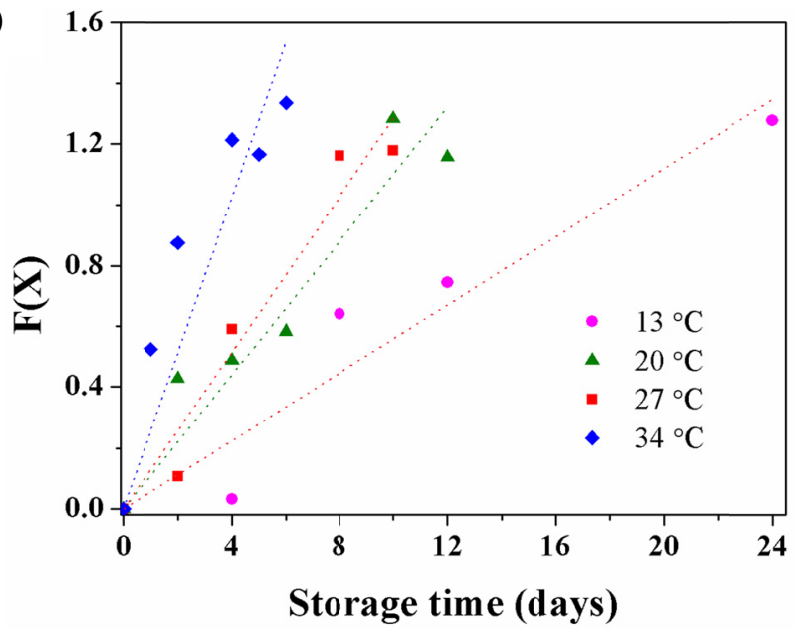




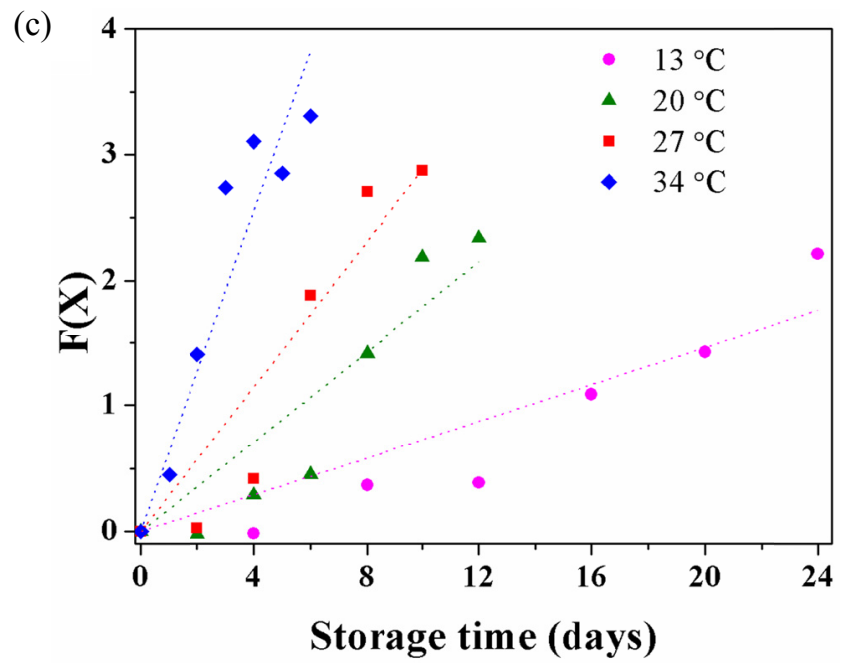

Figure 7. Plot of the response function $F(X)$ with storage time for (a) the firmness (b) the SSC value and (c) the TA value of 'Nam Dok Mai Si Thong' mango at different temperatures

Table 1. Response of rate constants $(\mathrm{k})$, the correlation coefficient $\left(\mathrm{R}^{2}\right)$ of the fit and activation energy $\left(E_{a}\right)$ obtained from the firmness, SSC and TA parameter model

\begin{tabular}{|c|c|c|c|c|c|}
\hline Parameter $(\mathrm{X})$ & $F(X)$ & Temperature $\left({ }^{\circ} \mathrm{C}\right)$ & $k$ & $R^{2}$ & $E_{a}\left(\mathrm{~kJ} \mathrm{~mol}^{-1}\right)$ \\
\hline \multirow[t]{4}{*}{ Firmness } & $\left(1 / X_{0}\right)-\left(1 / X_{\mathrm{t}}\right)$ & 13 & 0.0310 & 0.8361 & 46.45 \\
\hline & & 20 & 0.0370 & 0.9154 & \\
\hline & & 27 & 0.0646 & 0.9167 & \\
\hline & & 34 & 0.1116 & 0.7021 & \\
\hline \multirow[t]{4}{*}{ Soluble solid contents (SSC) } & {$[\ln \{1 /(1-X)\}]^{1 / 2}$} & 13 & 0.0560 & 0.9259 & 43.05 \\
\hline & & 20 & 0.0999 & 0.9192 & \\
\hline & & 27 & 0.1321 & 0.9547 & \\
\hline & & 34 & 0.2013 & 0.8717 & \\
\hline \multirow[t]{4}{*}{ Titratable acidity (TA) } & $\ln \left(X_{0}-X_{\mathrm{t}}\right)$ & 13 & 0.1073 & 0.8072 & 54.22 \\
\hline & & 20 & 0.2632 & 0.9380 & \\
\hline & & 27 & 0.3991 & 0.9458 & \\
\hline & & 34 & 0.5424 & 0.8070 & \\
\hline
\end{tabular}

\section{Conclusion}

Mangoes fruit 'Nam Dok Mai Si Thong' stored at different temperatures affected their qualities. The mango fruit kept at low temperature exposed delay in ripening and extended fruit shelf-life. A second-order kinetic model, a Gaussian model, and a first-order kinetic model fitted well with firmness, SCC, and TA changes during storage, respectively. The Arrhenius equation described well the temperature dependence on all factors considered. According with the results obtained, the storage temperature of $13{ }^{\circ} \mathrm{C}$ was the one that extended its shelf-life. This useful kinetic information of mangoes fruit 'Nam Dok Mai Si Thong' could be further employed for our future work in relation to a development of a ripeness indicator label as diagnostic packaging which is a subclass of intelligent packaging.

\section{References}

Ali, Z. M., Chin, L., \& Lazan, H. (2004). A comparative study on wall degrading enzymes, pectin modifications and softening during ripening of selected tropical fruits. Plant Science, 167(2), 317-327. https://doi.org/ 10.1016/j.plantsci.2004.03.030

AOAC. (2000). Acidity (Titratable) of fruit products with AOAC official method 920 (17th ed.). Official method 942.15. Washington, DC. 
Babalis, S. J., \& Belessiotis, V. G. (2004). Influence of the drying conditions on the drying constants and moisture diffusivity during the thin-layer drying of figs. Journal of Food Engineering, 65(3), 449-458. https://doi.org/10.1016/j.jfoodeng.2004.02.005

Baloch, M. K., \& Bibi, F. (2012). Effect of harvesting and storage conditions on the post harvest quality and shelf life of mango (Mangifera indica L.) fruit. South African Journal of Botany, 83, 109-116. https://doi.org/10.1016/j.sajb.2012.08.001

Bobelyn, E., Hertog, M. L. A T. M., \& Nicolaï, B. M. (2006). Applicability of an enzymatic time temperature integrator as a quality indicator for mushrooms in the distribution chain. Postharvest Biology and Technology, 42(1), 104-114. https://doi.org/10.1016/j.postharvbio.2006.05.011

Chiumarelli, M., Ferrari, C. C., Sarantópoulos, C. I. G. L., \& Hubinger, M. D. (2011). Fresh cut 'Tommy Atkins' mango pre-treated with citric acid and coated with cassava (Manihot esculenta Crantz) starch or sodium alginate. Innovative Food Science \& Emerging Technologies, 12(3), 381-387. https://doi.org/10.1016/j.ifset. 2011.02.006

Chongchatuporn, U., Ketsa, S., \& van Doorn, W. G. (2013). Chilling injury in mango (Mangifera indica) fruit peel: Relationship with ascorbic acid concentrations and antioxidant enzyme activities. Postharvest Biology and Technology, 86, 409-417. https://doi.org/10.1016/j.postharvbio.2013.07.023

Diaz-Perez, J. C., Bautista, S., \& Villanueva, R. (2000). Quality changes in sapote mamey fruit during ripening and storage. Postharvest Biology and Technology, 18(1), 67-73. https://doi.org/10.1016/S0925-5214(99) 00062-9

Famiani, F., Battistelli, A., Moscatello, S., Cruz-Castillo, J. G., \& Walker, R. P. (2015). The organic acids that are accumulated in the flesh of fruits: Occurrence, metabolism and factors affecting their contents - A review. Revista Chapingo Serie Horticultura, 21, 97-128.

Fonseca, S. C., Oliveira, F. A. R., \& Brecht, J. K. (2002). Modelling respiration rate of fresh fruits and vegetables for modified. Journal of Food Engineering, 52, 99-119. https://doi.org/10.1016/S0260-8774(01) 00106-6

Gomez, M. L. P. A., \& Lajolo, F. M. (2008). Ascorbic acid metabolism in fruits: activity of enzymes involved in synthesis and degradation during ripening in mango and guava. Journal of the Science of Food and Agriculture, 88(5), 756-762. https://doi.org/10.1002/jsfa.3042

Gupta, N., \& Jain, S. K. (2014). Storage behavior of mango as affected by postharvest application of plant extracts and storage conditions. Journal of Food Science and Technology, 51(10), 2499-2507. https://doi.org/10.1007/s13197-012-0774-0

Hernández, Y., Lobo, M. G., \& González, M. (2006). Determination of vitamin C in tropical fruits: A comparative evaluation of methods. Food Chemistry, 96(4), 654-664. https://doi.org/10.1016/j.foodchem. 2005.04.012

Hoa, T. T., \& Ducamp, M. (2008). Effects of different coatings on biochemical changes of 'cat Hoa loc' mangoes in storage. Postharvest Biology and Technology, 48(1), 150-152. https://doi.org/10.1016/j.postharvbio.2007. 09.021

Hong, S., \& Park, W. (2000). Use of color indicators as an active packaging system for valuating kimchi fermentation. Journal of Food Engineering, 46(1), 67-72. https://doi.org/10.1016/S0308-8146(00)00141-2

Iagher, F., Reicher, F., \& Ganter, J. L. M. S. (2002). Structural and rheological properties of polysaccharides from mango (Mangifera indica L.) pulp. International Journal of Biological Macromolecules, 31(1-3), 9-17. https://doi.org/10.1016/S0141-8130(02)00044-2

Ibarra-Garza, I. P., Ramos-Parra, P. A., Hernández-Brenes, C., \& Jacobo-Velázquez, D. A. (2015). Effects of postharvest ripening on the nutraceutical and physicochemical properties of mango (Mangifera indica L. cv Keitt). Postharvest Biology and Technology, 103, 45-54. https://doi.org/10.1016/j.postharvbio.2015.02.014

Kays, S. J. (1999). Preharvest factors affecting appearance. Postharvest Biology and Technology, 15(3), $233-247$. https://doi.org/10.1016/S0925-5214(98)00088-X

Ketsa, S., Chidtragool, S., Klein, J. D., \& Lurie, S. (1998). Effect of heat treatment on changes in softening, pectic substances and activities of polygalacturonase, pectinesterase and $\beta$-galactosidase of ripening mango. Journal of Plant Physiology, 153(3-4), 457-461. https://doi.org/10.1016/S0176-1617(98)80174-0 
Kienzle, S., Sruamsiri, P., Carle, R., Sirisakulwat, S., Spreer, W., \& Neidhart, S. (2012). Harvest maturity detection for 'Nam Dokmai \#4' mango fruit (Mangifera indica L.) in consideration of long supply chains. Postharvest Biology and Technology, 72, 64-75. https://doi.org/10.1016/j.postharvbio.2012.04.011

Medlicott, A. P., Reynolds, S. B., \& Thompson, A. K. (1986). Effects of temperature on the ripening of mango fruit (Mangifera indica L. var. Tommy Atkins). Journal of the Science of Food and Agriculture, 37(5), 469-474. https://doi.org/10.1002/jsfa.2740370506

Medlicott, A. P., Sigrist, J. M. M., \& Sy, O. (1990). Ripening of mangos following low-temperature storage. Journal of the American Society for Horticultural Science, 115(3), 430-434.

Mitra, S. K., \& Baldwin, E. Z. (1997). Mango. In S. K. Mitra (Ed.), Postharvest physiology and storage of tropical and subtropical fruits (pp. 85-122). CAB International, New York.

Nair, S., \& Singh, Z. (2009). Chilling injury during storage affects respiration rate and fruit quality in kensington pride mango fruit. Acta Horticulturae, 820, 737-744. https://doi.org/10.17660/ActaHortic.2009.820.92

Nopwinyuwong, A., Trevanich, S., \& Suppakul, P. (2010). Development of a novel colorimetric indicator label for monitoring freshness of intermediate-moisture dessert spoilage. Talanta, 81(3), 1126-1132. https://doi.org/10.1016/j.talanta.2010.02.008

O’Hare, T. (1995). Effect of ripening temperature on quality and compositional changes of mango (Mangifera indica L.) cv. Kensington. Australian Journal of Experimental Agriculture, 35(2), 259-263. https://doi.org/ 10.1071/EA9950259

Olivera, D. F., \& Salvadori, V. O. (2012). Kinetic modeling of quality changes of chilled ready to serve lasagna. Journal of Food Engineering, 110(3), 487-492. https://doi.org/10.1016/j.jfoodeng.2011.12.015

Pinheiro, J., Alegria, C., Abreu, M., Gonçalves, E. M., \& Silva, C. L. M. (2013). Kinetics of changes in the physical quality parameters of fresh tomato fruits (Solanum lycopersicum, cv. 'Zinac') during storage. Journal of Food Engineering, 114(3), 338-345. https://doi.org/10.1016/j.jfoodeng.2012.08.024

Schwaab, M., \& Pinto, J. C. (2007). Optimum reference temperature for reparameterization of the Arrhenius equation. Part 1: Problems involving one kinetic constant. Chemical Engineering Science, 62(10), 2750-2764. https://doi.org/10.1016/j.ces.2007.02.020

Sivakumar, D., Jiang, Y., \& Yahia, E. M. (2011). Maintaining mango (Mangifera indica L.) fruit quality during the export chain. Food Research International, 44(5), 1254-1263. https://doi.org/10.1016/j.foodres.2010. 11.022

Sothornvit, R., \& Rodsamran, P. (2008). Effect of a mango film on quality of whole and minimally processed mangoes. Postharvest Biology and Technology, 47(3), 407-415. https://doi.org/10.1016/j.postharvbio.2007. 08.005

Srinivasa, P. C., Baskaran, R., Ramesh, M. N., Harish Prashanth, K. V., \& Tharanathan, R. N. (2002). Storage studies of mango packed using biodegradable chitosan film. European Food Research and Technology, 215(6), 504-508. https://doi.org/10.1007/s00217-002-0591-1

Tefera, A., Seyoum, T., \& Woldetsadik, K. (2007). Effect of disinfection, packaging, and storage environment on the shelf life of mango. Biosystems Engineering, 96(2), 201-212. https://doi.org/10.1016/j.biosystemseng. 2006.10.006

Wang, B., Wang, J., Liang, H., Yi, J., Zhang, J., Lin, L., ... Jiang, W. (2008). Reduced chilling injury in mango fruit by 2,4-dichlorophenoxyacetic acid and the antioxidant response. Postharvest Biology and Technology, 48(2), 172-181. https://doi.org/10.1016/j.postharvbio.2007.10.005

Wills, R. H. H., McGlasson, B., Graham, D., \& Joyce, D. (1998). Postharvest: An Introduction to the Physiology and Handling of Fruit and Vegetable (p. 262). New South Wales University Press, New South Wales.

Yashoda, H. M., Prabha, T. N., \& Tharanathan, R. N. (2007). Mango ripening - Role of carbohydrases in tissue softening. Food Chemistry, 102(3), 691-698. https://doi.org/10.1016/j.foodchem.2006.06.001

Zaharah, S. S., \& Singh, Z. (2011). Postharvest nitric oxide fumigation alleviates chilling injury, delays fruit ripening and maintains quality in cold-stored 'Kensington Pride' mango. Postharvest Biology and Technology, 60(3), 202-210. https://doi.org/10.1016/j.postharvbio.2011.01.011 
Zheng, X., Tian, S., Gidley, M. J., Yue, H., \& Li, B. (2007). Effects of exogenous oxalic acid on ripening and decay incidence in mango fruit during storage at room temperature. Postharvest Biology and Technology, 45(2), 281-284. https://doi.org/10.1016/j.postharvbio.2007.01.016

Zhu, X., Wang, Q., Cao, J., \& Jiang, W. (2008). Effects of chitosan coating on postharvest quality of mango (Mangifera indica L. cv. Tainong) fruit. Journal of Food Processing and Preservation, 32(5), 770-784. https://doi.org/10.1111/j.1745-4549.2008.00213.x

\section{Copyrights}

Copyright for this article is retained by the author(s), with first publication rights granted to the journal.

This is an open-access article distributed under the terms and conditions of the Creative Commons Attribution license (http://creativecommons.org/licenses/by/4.0/). 